Vasvari, Louise O. "[English-Language] Bibliography of Interest for Hungarian Cultural Studies: 2012-2013."

Hungarian Cultural Studies. e-Journal of the American Hungarian Educators Association, Volume 6 (2013):

http://ahea.pitt.edu DOI: 10.5195/ahea.2013.123

\title{
[English-Language] Bibliography of Interest for Hungarian Cultural Studies: 2012-2013
}

\author{
Louise O. Vasvári
}

Abstract: As the above title indicates, this bibliography straddles 2012-2013, covering the period since the publication in Fall of 2012 of last year's bibliography in this journal. Each yearly bibliography is supplemented by earlier items that were only retrieved recently. Although this bibliography can only concentrate on English-language items, occasional items of particular interest in other languages are included.

For a more extensive bibliography of Hungarian Studies from about 2000 to 2010, for which the AHEA yearly bibliographies are an update, see Louise O. Vasvári, Steven Tötösy de Zepetnek, and Carlo Salzani. "Bibliography for Work in Hungarian Studies as Comparative Central European Studies." CLCWeb: Comparative Literature and Culture (Library) (2011): http://docs.lib.purdue.edu/clcweblibrary/hungarianstudiesbibliography.

Biography: Louise O. Vasvári, who received her M.A. and Ph.D. at the University of California in Berkeley, is Professor Emerita of Comparative Literature and of Linguistics at Stony Brook University. She has also taught in various visiting capacities, including at the University of California, Berkeley, at the Eötvös Loránd University and at the Central European University in Budapest, the University of Connecticut (Storrs), and the Universite de Jules Verne (Amiens). Currently she teaches one course yearly in the linguistics department at New York University and is also Affiliated Professor in American and English Studies at the University of Szeged, Hungary. She works in medieval studies, historical and socio-linguistics, translation theory, Holocaust studies, and Hungarian Studies, all informed by gender theory within a broader framework of comparative cultural studies.

Ács, Pál. 2010. “The 'Cultural Patriotism' of Benedek Komjáti.' Whose Love of Which Country? Composite States, National Histories and Patriotic Discourses in Early Modern East Central Europe. Balázs Trencsényi, Márton Zászkaliczky, eds. Leiden: Brill: 75-90.

Akcah, Emel and Umut Korkut. 2012. "Geographical Metanarratives in East-Central Europe: Neo-Turanism in Hungary." Eurasian Geography and Economics 53.3: 596-614.

Apor, Balázs, Péter Apor, and E. A. Rees. eds. 2008. The Sovietization of Eastern Europe: New Perspectives on the Postwar Period. Washington DC: New Academic Publishing.

Apor, Balázs, Jan C. Behrends, Polly Jones, E. A. Rees, eds. 2004. The Leader Cult in Communist Dictatorship: Stalin and the Eastern Block. New York: Palgrave MacMillan.

Bak, János. 2012. "Twelve Jewish Boys from the Class of ' 47 of a Budapest Grammar School and Their Families. Memories and Reminiscences." East European Jewish Affairs 42.3: 243-323. 
Vasvari, Louise O. "[English-Language] Bibliography of Interest for Hungarian Cultural Studies: 2012-2013.”

Hungarian Cultural Studies. e-Journal of the American Hungarian Educators Association, Volume 6 (2013):

http://ahea.pitt.edu DOI: 10.5195/ahea.2013.123

Bán, Zsófia. 2012. "Forgács’s Film and Installation Dunai Exodus." CLCWeb Comparative Literature and Culture $14.5 \mathrm{http}: / / \mathrm{x} . \operatorname{diorg} / 10.7771 / 1481=4374.2144$

Bárdi, Nándor, Csilla Fedinec, and László Szarka. eds. 2011. Minority Hungarian Communities in the Twentieth Century. Trans. Brain McLean. Boulder: Atlantic Research and Publications Inc, Institute for Ethnic and National Minority Studies of the Hungarian Academy of Sciences, Social Sciences Monographs.

Barenscott, Dorothy. 2010. "Trafficking in Photographs: Representational Power and the Case of Lajos Kossuth, Budapest, 1894. History and Memory 22.2: 34-67.

Blomqvist, Anders, Constantin Iordachi and Balázs Trencsényi, eds. 2013. The Entanglement of Hungarian and Romanian History. Oxford: Peter Lang.

Boromisza-Habashi, David. 2013. Speaking Hatefully: Culture, Communication and Political Action in Hungary. University Park: Pennsylvania State UP.

Brubacker, Rogers and Margit Feischmidt. 2002. "1848 in 1998: The Politics of Commemoration in Hungary, Romania, and Slovakia." Comparative Studies in Society and History 44: 700-747.

Cartledge, Bryan. 2010. The Will to Survive. A History of Hungary. New York: Columbia UP [reviewed by Gábor Vermes: https://www.h-net.org/reviews/showrev.php?id=35342

Cserepes, Tünde. 2012. "Measuring Identity Changes Analysing Fragments from the Diary of Sándor Károly with Social Network Analysis.” European Review of History 19.5: 729-748.

Czigányik, Zsolt. 2011. "Literature and Censorship in the Kádár Era in Hungary,” In British Literature in the Hungarian Cultural Memory. Bálint Gárdos, Ágnes Péter, Natália Pikli, and Maté Vince, eds.: 223

Dávid, Gyula. 2012. "The Inconvenient Grand Seigneur. The Memory of Miklós Banffy.” Hungarian Review 4.1: 92-102.

Dávidházy, Péter. 2011. "Can These Bones Live? The "Waste Land,” Ezekiel and Hungarian Poetry. In British Literature in the Hungarian Cultural Memory. Bálint Gárdos, Ágnes Péter, Natália Pikli, and Maté Vince, eds.: 87-122.

Davis, R. Chris. 2010. "Nationalizing the Moldavian Csangos: Clericalism and Ethnic Mobilization in World War II Romania and Hungary." Re-Contextualizing East Central European History: Nation, Culture and Minority Group. Robert Pyrah and Marius Turda, eds. Oxford: Oxford UP.

Dénes, Iván Zoltán. 2012. "Adopting the European Model Versus National Egoism: The Task of Surpassing Political Hysteria.” European Review 20.4: 514-525. 
Vasvari, Louise O. "[English-Language] Bibliography of Interest for Hungarian Cultural Studies: 2012-2013.”

Hungarian Cultural Studies. e-Journal of the American Hungarian Educators Association, Volume 6 (2013):

http://ahea.pitt.edu DOI: 10.5195/ahea.2013.123

Derwin, Susan. 2012. “Art of Healing: Imre Kertész's Fatelessness.” Rage Is the Subtext. In id. Readings in Holocaust Literature and Film. Columbus: Ohio State UP: 79-105.

Feischmidt, Margit. 2008. "The Hungarian Transylvania: Symbolic Reconstruction of Lost Territories.” Hungarian Studies 22.1: 119-133.

Gantner, Eszter and Mátyás Kovács. 2012. "Altering Alternatives. Mapping Subcultures in Budapest.” Julia Brauch, Anna Lipphardt, and Alexandra Nocke, eds. Jewish Topographies. Visions of Space, Traditions of Place. New York: Ashgate: 139-160.

Gárdos, Bálint, Ágnes Péter, Natália Pikli, and Maté Vince, eds. 2011. Confrontations and Interactions. Essays on Cultural Memory. Budapest: L'Harmattan http://seas3.elte.hu/angolpark/CultMem/EssaysonCulturalMemory.pdf

Gerö, András. 2010. Neither Women Nor Jews: The Confluence of Prejudices in the AustroHungarian Monarchy at the Turn of the Century. Trans. Thomas J. DeKornfeld and Helen D. De Kornfeld. Boulder: Social Science Monographs.

Giustino, Cathleen M., Catherine J. Plum, and Alexander Vari, eds. Socialist Escapes: Breaking Away from Ideology and Everyday Routine in Eastern Europe: 1945-1989. Oxford: Berghahn.

Gottlieb, Erika. 2001. Dystopian Fiction East and West: Universe of Terror and Trial. Montreal: McGill-Queens UP.

Greskovits, George. 2012. "Re-presenting Moral Ambivalence: Narratives of Political Monologue Regarding András Hegedüs and Pál Teleki." European Review of History 19.5: 749.

Grudzinska-Gross, Irena and Andrzej Tymowski, eds. 2013. Eastern Europe: Women in Transition. Frankfurt: Peter Lang.

Hames, Peter, ed. 2004. The Cinema of Central Europe. London: Wallflower P.

Hartvig, Gabriella. 2011. "Shandean Originality and Humor in Ferenc Kölcsey's “Forword.” In British Literature in the Hungarian Cultural Memory. Bálint Gárdos, Ágnes Péter, Natália Pikli, and Máté Vince, eds.: 123-134.

Hites, Sándor. 2012. "Variations on Mother Tongue. Language and Identity in TwentiethCentury Hungarian Exile." Hungarian Historical Review 1.3-4: 454-474.

Jones, Gwen. 2013. Chicago of the Balkans. Budapest in Hungarian Literature 1900-1939. Oxford: Oxford UP.

Kállay, Géza. 2011. "A Stain of Blood as Cultural Transmission - Lady Macbeth and János Arany's "Goodwife Ágnes." In British Literature in the Hungarian Cultural Memory. Bálint Gárdos, Ágnes Péter, Natália Pikli, and Maté Vince, eds.: 135-146. 
Vasvari, Louise O. "[English-Language] Bibliography of Interest for Hungarian Cultural Studies: 2012-2013."

Hungarian Cultural Studies. e-Journal of the American Hungarian Educators Association, Volume 6 (2013):

http://ahea.pitt.edu DOI: 10.5195/ahea.2013.123

Kehoe, Ryan Michael. 2009. "Necropolitics and Contemporary Hungarian Literature and Cinema." CLCWeb: Comparative Literature and Culture 11.4 http://dx.doi.org/10.7771/1481$\underline{4374.1562}$

Kenyeres, János. 2011. “1956 in Cultural Memory: The Testimony of Literature.” In British Literature in the Hungarian Cultural Memory. Bálint Gárdos, Ágnes Péter, Natália Pikli, and Maté Vince, eds.: 59-70.

Kerekes, Janet. 2005. Masked Ball at the White Cross Café. The Failure of Jewish Assimilation. Lanham: UP of America.

Kérchy, Anna. 2012. "From Showbiz to the Concentration Camp: The Fabulous, Freakish Life of Hungarian Jewish 'Dwarf' Performers Zoli Hirsch and the Ovitz Family.” Exploring the Cultural History of Continental European Freak Shows and 'Enfreakment.' Anna Kérchy and Andrea Zittlau, eds. Newcastle: Cambridge Scholars Publications: 211-232.

Kern, Catharina and Evelyn Eichmüller. 2006. Politeness Strategies in Hungary and England With Special Focus on Greetings and Leave-Taking Terms. Norderstedt: GRIN Verlag.

Kind-Kovács, Friederike. 2013. "Voices, Letters and Literature Through the Iron Curtain: Exiles and the (Trans)mission of Radio in the Cold War." Cold War History 13.2: 193-213.

Kind-Kovács, Friederike. 2013. "Radio Free Europe and Radio Liberty as the 'Echo Chamber' of Tamizdat," Samizdat, Tamizdat and Beyond. Transnational Media During and After Socialism. F. Kind-Kovács and Jessie Labov, eds. New York: Berghahn: 70-93.

Kisbán, Eszter. 2012. "Health, Hogs, Hungaricums: Revitalization of Traditional Food in Hungary." Time for Food: Everyday Food and Changing Meat Habits in a Global Perspective. Patricia Lysagh and Anna Aström, eds. Turku: Abo Akademia UP: 117-141.

Komporaly, Jozefina and Márta Minier. 2008. "Adaptation, Translation, Multimediality: A Hungarian Bestseller Across Cultures." Journal of Adaptation in Film and Performance 1.3: 191-204.

Korompay, Klára. 2012. "Hungary: Sixteenth-Century Hungarian Orthography.” Orthographies in Early Modern Europe. Susan Baddeley, ed. Berlin: De Gruyter Mouton: 321-349.

Kósa, Magda Kovács and Andrea Pető. 2007. Balance Sheet. Disadvantaged Social Groups in Hungary. Budapest: Napvilág and Táncsis Mihály Foundation.

Kovács, András. 2010. The Stranger at Hand: Antisemitic Prejudices in Post-Communist Hungary. Leiden: Brill.

Kovács, Anna Zsófia. 2012. "Milton Dictating to His Daughters: Varieties on a Theme from Füssli to Munkácsy." Milton Through the Centuries. Gábor Itzés and Miklós Peti, eds. Budapest: L'Harmattan: 322-337. 
Vasvari, Louise O. "[English-Language] Bibliography of Interest for Hungarian Cultural Studies: 2012-2013.”

Hungarian Cultural Studies. e-Journal of the American Hungarian Educators Association, Volume 6 (2013):

http://ahea.pitt.edu DOI: 10.5195/ahea.2013.123

Kovács, Katalin and Mónika Váradi. 2000. "Women’s Life Trajectories and Class Formation in Hungary." Reproducing Gender: Politics, Publics and Everyday Life after Socialism. Susan Gal and Gail Klingman eds. Princeton: Princeton UP: 176-199.

Lazaroms, Ilse Josepha. 2013. "Chance Survivor, by Andrew Karpati Kennedy, and The Summer My Father Died, by Yudit Kiss.” Jewish Quarterly 60.1: 71-73.

Laczó, Ferenc and Máté Zombory. 2012. "Between Transnational Embeddedness and Relative Isolation: The Moderate Rise of Memory Studies in Hungary." Acta Poloniae Historica 106: 99.

Lyon, Jonathan R. 2012. "The Letters of Princess Sophia of Hungary, a Nun at Admont." Writing Medieval Women's Lives. Charlotte Newman and Amy Livingstone, eds. NY: Palgrave McMillan: 51-68.

Maitz, Peter. 2007. "The Death of Standard German in Nineteenth-Century Budapest. A Case Study on the Role of Linguistic Ideologies in Language Shift." Germanic Language Histories "From Below." (1700-2000). Nils Langer et al. eds. Berlin: De Gruyter: 405-422.

Manchin, Anna. 2012. "Imagining Modern Hungary Through Film: Debates on National Identity, Modernity and Cinema in Early Twentieth-Century Hungary." Cinema, Audienes and Modernity: New Perspectives in European Cinema in Hungary. Daniel Bittereyst, Richard Maltby, and Phylippe Meers, eds. London: Routledge: 64-80

Maráczi, Géza. 2011. "László Cs. Szabó on Dickens: A Case Study on a "Western Hungarian" Perspective." In British Literature in the Hungarian Cultural Memory. Bálint Gárdos, Ágnes Péter, Natália Pikli, and Maté Vince, eds: 223-234.

Michlic, Johanna and John Paul Himka, ed. 2013. Bringing the Past to Light: The Reception of the Holocaust in Post-Communist Hungary. Lincoln: U of Nebraska.

Miklósi, Zoltán and Andrew Arató. 2010. "Constitution Making and Transitional Politics in Hungary, 1989-1999." Framing the State in Time of Transition. Laurel E. Miller ed.Washington D.C.: U. S. Institute of Peace.

Minier, Márta. 2013. “Recruiting the Bard' for Socialism: Introducing Margit Gáspár's Hamlet Is Not Right as Testimony and Shakespearean Appropriation. Rhytmos 1. 1: 74-96.

Minier, Márta. 2012.'Hamlet, Petőfi and the Poet's Mandate: Poems by János Arany, Éva Finta and Gábor Tompa:' Hamlet and Poetry." New Readings 2012: 91-106.

Minier, Márta. 2012. "Tracing a Text of Identity: Hungarian Hamlet Poetry." Reworking Hamlet for European Cultures. Ruth J. Owen, ed. Newcastle Upon Tyne: Cambridge Scholars: 31-43.

Miron, Guy. 2011. The Waning of Emancipation: Jewish History, Memory, and the Rise of Fascism in Germany, France, and Hungary. Detroit: Wayne State. 
Vasvari, Louise O. "[English-Language] Bibliography of Interest for Hungarian Cultural Studies: 2012-2013.”

Hungarian Cultural Studies. e-Journal of the American Hungarian Educators Association, Volume 6 (2013):

http://ahea.pitt.edu DOI: 10.5195/ahea.2013.123

Munteán, Lászlo. 2011. “Under the Urban Skin: Counter-Monumental Configurations of the Bombings of Budapest in the Second World War." In British Literature in the Hungarian Cultural Memory. Bálint Gárdos, Ágnes Péter, Natália Pikli, and Maté Vince, eds.: 43-58.

Péter, Ágnes. 2011. “The Romantic Myth of Milton in Hungary: Mór Jókai’s Milton.” In British Literature in the Hungarian Cultural Memory. Bálint Gárdos, Ágnes Péter, Natália Pikli, and Maté Vince, eds.: 191-212.

Petö, Andrea. 2012. "Women and Victims and Perpetrators in World War II: The Case of Hungary." Women and Men at War. A Gender Perspective on World War II and Its Aftermath in Central and Eastern Europe. Maren Röger and Ruth Leiserowitz, eds. Osnabrück: Fibre V: 81.

Petö, Andrea. 2013. "Historicizing Hate: Testimonies and Photos About the Holocaust Trauma During the Hungarian Post-World War II Trials." Tapestry of Memory. Evidence and Testimony in Life Story Narratives. Nancy Adler, Selma Leydesdorff, eds. NY: Transaction Publishers: 3.

Pikli, Natalia. 2011. "Teenagers in Focus - Classic/Popular Shakespeare? A Case Study of Present-Day Hungarian Reception." In British Literature in the Hungarian Cultural Memory. Bálint Gárdos, Ágnes Péter, Natália Pikli, and Maté Vince, eds.: 235-258.

Pyrah, Robert and Marius Turda, eds. 2010. Re-Contextualizing East Central European History: Nation, Culture and Minority Group. Oxford: Oxford UP.

Rosen, Ilana. 2012. "Soldiers or Slaves? Narratives of Survivors of the Hungarian Army's 'Labor Service' in World War II and the Holocaust." DAPIM. Studies on the Holocaust 26: 95.

Royer, Clara. 2011. Le Royaume littéraire: quêtes d'identité d'une generation d'écrivains juifs de l'entre-deux guerres. Paris: Honoré Champion.

Schandl, Veronika. 2012. "History Interrupted: Hamlet and 1956 in Hungary." Reworking Hamlet for European Cultures. Ruth J. Owen, ed. Newcastle Upon Tyne: Cambridge Scholars: 105-114.

Schandl, Veronika. 2012. "So Berattle the Common Stages: Metatheatricality and Polyfunctionality in Two Hungarian Shakespeare Productions." Early Modern Communi(cat)ions: Studies in in Early Modern English Literature and Culture. Newcastle Upon Tyne: Cambridge Scholars: 135-152.

Sherwood, Peter. 2012. "Crater into Well: Sex and Violence in Kosztolányi's Édes Anna and its English Translation." Translation Review 55.1: 34-38.

Sherwood, Peter. 2005. "Living Through Something: Notes on the Work of Imre Kertész." In Joseph Sherman and Ritchie Robertson, eds. The Yiddish Presence in European Literature. Inspiration and Interaction. Oxford: Oxbow Books: 108-116.

Thompson, Mark. 2012. Birth Certificate: The Story of Danilo Kis. Ithaca: Cornell UP. 
Vasvari, Louise O. "[English-Language] Bibliography of Interest for Hungarian Cultural Studies: 2012-2013."

Hungarian Cultural Studies. e-Journal of the American Hungarian Educators Association, Volume 6 (2013):

http://ahea.pitt.edu DOI: 10.5195/ahea.2013.123

Timár, Andrea. 2011. "The Poetics and Politics of Memory in the Romantic Period." In British Literature in the Hungarian Cultural Memory. Bálint Gárdos, Ágnes Péter, Natália Pikli, and Maté Vince, eds.: 365-382.

Tötösy de Zepetnek, Steven. 2012. "Nádas's A Book of Memories and Central European Journey." CLCWeb: Comparative Literature and Culture 14.5 http://dx.doi.org/10.7771/1481$\underline{4374.2157}$

Turda, Marius. 2010. "Entangled Traditions of Race: Physical Anthropology in Hungary and Romania, 1900-1940." Focaal: Journal of Global and Historical Anthropology 58: 32-46.

Vári, Alexander. 2013. "The Nation in the City: Ceremonial (Re)burials and Patriotic Mythmaking in Turn-of-the-Century Budapest.” Urban History 40.2:202-205

Vári, Alexander. 2012. "Re-territorializing the "Guilty City"” Nationalist and Right-Wing Attempts to Nationalize Budapest during the Interwar Period." Journal of Contemporary History 47.4: 709-733.

Vári, Alexander. 2011. "From 'Paris of the East' to 'Queen of the Danube:' Transnational Models of the Promotion of Budapest Tourism, 1885-1940." Touring Beyond the Nation: A Transnational Approach to European Tourism, Tourism History. Eric G. E. Zuelow, ed. Franham: Ashgate: 103-125.

Végső, Roland. 2013. "Stalin's Boots and the March of History. Post-Communist Memoirs." Cultural Critique 83: 31-62.

Végsö, Roland. 2012. The Naked Communist: Cold War Modernism and the Politics of Popular Culture. New York: Fordham UP.

Velich, Andrea. 2011. "The Cemetery as a Space of Remembering and Forgetting: The Pollution of Burial Grounds in England and Hungary.” In Bálint Gárdos, Ágnes Péter, Natália Pikli, and Maté Vince, eds.: 327-340.

Vince, Máté. 2011. “The One Single Story Falls to 1956 Pieces: Papp and Terey’s Kazamatek and the Memories of the Revolution." In British Literature in the Hungarian Cultural Memory. Bálint Gárdos, Ágnes Péter, Natália Pikli, and Maté Vince, eds.: 295-316.

Weaver, Eric Beckett. 2010. "More Hungarian Hungarians, More Human Humans: Social and National Discourse on Hungarian Minorities in the Interwar Period." Re-Contextualizing East Central European History. Nation, Culture and Minority Groups. Robert Pyrah and Marius Turda. Oxford: Legenda.

Zombory, Máté. 2012. Maps of Remembrance: Space, Belonging and Politics of Memory in Eastern Europe. Budapest: L'Harmattan. 